АНАЛІЗ ПРОБЛЕМИ АКТИВІЗАЦІЇ САМОВДОСКОНАЛЕННЯ ТА ТВОРЧОГО ПОШУКУ МАЙБУТНІХ ОФІЦЕРІВ ЗБРОЙНИХ СИЛ УКРАЇНИ

\title{
THE PROBLEM ANALYSIS OF ENHANCING SELF-IMPROVEMENT AND CREATIVE SEARCH OF FUTURE UKRAINE ARMED FORCES OFFICERS
}

\begin{abstract}
Проблеми активізації самовдосконалення та творчого пошуку у просесійній діяльності $є$ об'єктом дослідження багатьох учених. Самовдосконалення розглядається як один із найважливіших чинників успішної просресійної діяльності, що сприяє прагненню до самореалізації особистості, визначення себе як профресіонала. Найвищою ланкою такої особистості є творчий підхід до виконання посадових обов'язків, виявлення доречної ініціативи, впровадження нових шляхів під час рішення військово-прикладних завдань. У статті розглядаються шляхи активізації самовдосконалення та творчого пошуку, доцільних для використання у процесі фрормування готовності майбутніх офріцерів Збройних сил України до застосування STEM-технологій у профессійній діяльності. Основними ффункціями самовдосконалення та творчого пошуку є фуункиія самопізнання, самооцінки, самопроєктування, самокорекції тощо. Одним із чинників, що впливає на ці процеси, є сумісна діяльність курсантів та педагогів. Розуміючи вимоги сучасності, для якісної підготовки майбутніх офріцерів до виконання професійних обов'язків науковопедагогічний колектив закладу вищої військової освіти повинен активно впроваджувати інноваційні методи викладання під час організації освітнього процесу.

у статті запропоновано засоби активізаціі самовдосконалення та творчого пошуку під час вирішення військово-прикладних завдань у процесі фрормування готовності майбутніх офріцерів Збройних сил України до застосування STEM-технологій у їхній профресійній діяльності. Серед них: утілення ідеї активізації постійного самовдосконалення у процес викладання всіх дисциплін; під час навчальних занять створення умов, які сприяють обговоренню наявних проблемних питань в ЗС України та передумов для їх рішення; надання курсантам можливості самостійно висувати пропозиції щодо поліпшення шляхів вирішення типових військово-прикладних завдань, застосовуючи STEM-технології, які впроваджуються в освітній прочес шляхом використання інформаційно-комунікаційних технологій; надання консультацій та допомоги для більш детального дослідження проблеми, яка зацікавила тих, хто навчається; сприяння творчому пошуку майбутніх фрахівців.
\end{abstract}

старший викладач кафедри

фундаментальних наук

Військової академії (м. Одеса)
Ключові слова: майбутні офріцери, самовдосконалення, творчий пошук, готовність до застосування STEM-технологій.

The problems of enhancing self-improvement and creative search in professional activity are the subject of research by many scientists. Selfimprovement is considered as one of the most important factors of successful professional activity, contributes to the desire for self-realization of the individual, definition of himself as a professional. The highest achievement of the individual is the creative approach to the performance of official duties, the manifestation of appropriate initiative, the introduction of new methods of solving military-applied tasks. The article considers ways to intensify self-improvement and creative search, which is appropriate for use in the process of formation of readiness of future Ukraine Armed Forces officers to use STEM-technologies in professional activity.

One of the factors affecting these processes is the joint activity of cadets and teachers. In order to prepare future officers for professional duties and, understanding the requirements of modern times, the scientific and pedagogical staff of the higher military educational institution should actively introduce innovative methods of teaching in the organization of the educational process. The article proposes means to intensify selfimprovement and creative search in solving military-applied tasks in the process of forming readiness of future officers of the Armed Forces of Ukraine to apply STEM-technologies in their professional activities. Among them: translating the idea of intensifying constant self-improvement into the process of teaching all disciplines; Creation of such conditions during training sessions, which contribute to the development of discussion about problematic issues in the Armed Forces of Ukraine, prerequisites for their solution; Providing cadets with the opportunity to put forward ideas to improve options for solving typical military applications by using STEM technologies, which are implemented through the use of information and communication technologies; Providing advice and assistance for a more detailed study of the problem that has affected students; Facilitating creative search for future specialists.

Key words: future officers, self-improvement, creative search, of readiness to use STEMtechnologies.
Постановка проблеми в загальному вигляді. Сучасний стан Збройних сил (3С) України, зміни у військовій освіті вимагають нових тенденцій у фрормуванні керівного складу всіх рівнів військового управління, тому професійна підготовка майбутніх офріцерів має враховувати багато нових аспектів, які є постійним об'єктом дослідження вчених.

Аналіз останніх досліджень і публікацій. Питаннями самовдосконалення та різними аспектами впливу на цей процес під час підготовки фрахівців різних спеціалістів займалися Н. Уйсім- баєва, Т. Яблонська, І. Уличний, С. Хатунцева, Н. Леоненко, О. Слободян, І. Ларина та ін.

Процеси самовдосконалення та розвитку творчого пошуку військових фрахівців під час виконання професійних обов'язків досліджували М. Демент, О. Діденко, Ю. Лісніченко, О. Маслій, Ю. Ненько, О. Царенко та ін.

Виділення не вирішених раніше частин загальної проблеми. Ми розглядаємо професійну підготовку офріцерів 3С України як формування їх готовності до застосування STEM-технологій 
у профресійній діяльності, 3 приводу чого нами були сорормульовані педагогічні умови фрормування зазначеної готовності [4] у освітньо-виховному середовищі закладу вищої військової освіти (ЗВВО), однією 3 яких є активізація постійного самовдосконалення та творчого пошуку під час вирішення військово-прикладних завдань.

Профресійне самовдосконалення $€$ суспільно та особистісно необхідною умовою становлення курсантів як майбутніх офріцерів. Під професійним самовдосконаленням майбутніх офріцерів (за О. Діденко) розуміємо поєднання взаємопов'язаних і взаємозалежних процесів: профресійного самовиховання як цілеспрямованої активної діяльності та професійної самоосвіти як цілеспрямованої роботи щодо розширення і поглиблення своїх профресійних знань, удосконалення та набуття відповідних навичок та вмінь під час навчання у 3 ВВО [2].

Мета статті. Метою роботи є висвітлення засобів активізації самовдосконалення та творчого пошуку майбутніх офріцерів 3С України до застосування STEM-технологій у професійній діяльності.

Виклад основного матеріалу. О. Маслій, розглядаючи особливості підготовки майбутніх офріцерів тилу у сорері військово-економічної логістики, виділяє чинники, що впливають на фрормування майбутніх офріцерів: підвищення кваліфікації військових науково-педагогічних кадрів, фрормування творчого мислення військового спеціаліста, здатного продуктивно вирішувати складні питання військово-профресійної діяльності [8]. Тобто інноваційна діяльність педагогів та курсантів у освітньому процесі ВВН3 відображає сукупність нових фрорм організації роботи суб'єктів освітнього процесу.

Так, О. Царенко, фрормуючи позитивну мотивацію до освітньо-ігрового проєктування, вважає доцільним використання всього комплексу методів стимулювання освітньо-пізнавальної діяльності [14].

На думку Н. Уйсімбаєвої, самовдосконалення відбувається завдяки прагненню кожної людини до досконалості, наближення до певного ідеалу 3 метою набуття відповідних рис і якостей або їх удосконалення [10]. Самовдосконалення $€$ найважливішим методом фрормування себе не тільки як профресіонала, а й передусім як особистості [2].

Особа з актуалізованою потребою у самовдосконаленні, як уважає Т. Яблонська, характеризується виразною спрямованістю на гуманістичні цінності, зв'язком мотивів роботи над собою 3 духовним ядром особистості, стійкістю цілей і завдань самовдосконалення, перетворенням їх на домінанту життєдіяльності, володінням необхідними для самовдосконалення вміннями, високим рівнем самостійності й готовності до творчої діяльності [15].
Обґрунтовуючи сутність ціннісного ставлення до майбутньої профресії офріцера, Ю. Ненько зауважує, що ціннісний складник повинен бути пов'язаний із соціальними цінностями, серед яких - прагнення до самоосвіти, самовдосконалення, самореалізація тощо [9, с. 256]. Своєю чергою, структуру стимулювання ціннісного ставлення до просресійної діяльності М. Демент представляє у вигляді поєднання таких компонентів: смислового, когнітивного, емоційно-оцінного, діяльнісновольового [1].

Основними фрормами самовдосконалення майбутніх фрахівців І. Уличний називає самоосвіту і самовиховання. При цьому автор виділяє чотири основні логічно взаємопов'язані етапи: свідоме прийняття рішення на самовдосконалення; планування і вироблення програми самовдосконалення; практична діяльність із реалізації завдань у роботі над собою; самоконтроль і самокорекція діяльності із самовдосконалення [11].

Ю. Лісніченко у своєму дослідженні серед основних шляхів реалізації системи підготовки майбутніх офріцерів високомобільних десантних військ до профресійної діяльності у процесі вивчення фрахових дисциплін виокремлює лекційну роботу, спрямовану на фрормування теоретичної компетентності у сорері військової підготовки та позитивної мотивації до вивчення фрахових дисциплін із подальшою метою на самовдосконалення та саморозвиток у визначеному напрямі [7].

Для активізації самовдосконалення та творчого пошуку майбутніх офріцерів ЗС України під час вирішення військово-прикладних завдань, на нашу думку, необхідною умовою $є$ самоусвідомлення науково-педагогічними працівниками значущості самовдосконалення крізь процес самоосвіти.

Пріоритетною потенцією самовдосконалення, як переконує С. Хатунцева, є саморозвиток особистості, основою якого $€$ розгортання сутності людини через її індивідуальність. Спираючись на думку дослідниці щодо специфрічної характеристики активності майбутніх фрахівців [13], зазначимо, що у майбутніх офріцерів такою характеристикою може бути усвідомлена профресійна спрямованість особистості, що виявляється у розумінні значущості профресії офріцера, вмотивованості до постійного вдосконалення та наявності стійкого інтересу до професійної діяльності і, як наслідок, творчому пошуку під час вирішення військово-прикладних завдань, у тому числі за допомогою інфрормаційнокомунікаційних технологій, що є не характерною рисою для ЗВВО.

Нам імпонує думка Н. Леоненко та О. Слободян, які визначають творчий саморозвиток особистості як умотивовану, свідому, відрефлексовану на основі самопізнання, самовизначення, самоконтролю, самоосвіти діяльність, спрямовану на самовдосконалення природних та духовних якос- 
тей, на розвиток творчого потенціалу, на моделювання власного способу життя в соціокультурному контексті, на самореалізацію творчих здібностей у процесі життєтворення та профресійного становлення [6]. Творчість - це найвища і специфічна форма розвитку, здатна виявлятися в будь-яких copepax індивідуальності людини. Профресійна творчість офріцера, на думку О. Діденко, передбачає нестандартне використання методів, способів та засобів під час вирішення професійних завдань, уміння відхилятися у разі потреби від традиційних схем мислення, швидко вирішувати нетипові проблеми, складні завдання та впевнено діяти у непередбачених ситуаціях, по-новому дивитися на звичне, типове, повсякденне у найрізноманітніших умовах профресійної діяльності [3].

Поштовхом до активізації $€$ психологічний перелом, який демонструє перехід від зовнішньої детермінації життєдіяльності до внутрішньої, прагнення до самозмін стимулює до прояву творчого пошуку майбутніх ооріцерів 3С України під час вирішення військово-прикладних завдань.

І. Уличний розкриває поняття професійного самовдосконалення крізь низку принципів. Залежність рівня розвитку, самоосвіти, самовиховання та зрілості особистості розкриває принцип розвитку, який $\epsilon$ метою і сенсом усього життя. Профресійна діяльність задає напрям розвитку особистості, що служить творчому, постійному самовдосконаленню [12].

І. Ларина та В. Сиромятникова вважають, що процес професійного самовдосконалення буде продуктивним, якщо у цей процес будуть включені: мотиви досягнення й творчого пошуку; особистісні соціально-значущі мотиви; мотиви, пов'язані 3 результативністю діяльності; мотиви запобігання неприємностям та ін. [5].

Ми переконані, що у процесі активізації самовдосконалення головним $є$ усвідомлення особистістю необхідності корекційної роботи над собою. Розуміння власних недоліків, бажання їх подолати, встановлення мети, розроблення плану заходів щодо самовдосконалення, збір необхідних даних, вивчення методів вирішення військовоприкладних завдань іншими фрахівцями, здатність до аналізу та систематизації отриманого досвіду на основі власних компетентностей свідчать про високий рівень самоорганізації. Лише цілеспрямована самостійна робота над собою, прагнення до поліпшення професійних якостей, здатність до самокритики, самоконтролю спонукають майбутніх офріцерів до подальшого розвитку, що призводить до розкриття творчого потенціалу. А власний творчий пошук у процесі вирішення військово-прикладних завдань веде до самореалізації та професійної майстерності, що є необхідною умовою для успішної кар'єри сучасного офріцера ЗС України.

Висновки. Головною ідеєю процесу активізації самовдосконалення та творчого пошуку осо- бистості є створення таких умов, коли курсанти, маючи свободу мислення, самостійно прагнуть до вивчення різних предметних сорер через виконання різного типу індивідуальних завдань, пропонуючи власні пропозиції щодо вирішення поставлених завдань.

Ми пропонуємо такі засоби активізації самовдосконалення та творчого пошуку майбутніх офіцерів 3С України під час вирішення військовоприкладних завдань: утілення ідеї активізації постійного самовдосконалення у процес викладання всіх дисциплін; створення таких умов під час аудиторних занять, які сприяють обговоренню наявних проблемних питань у ЗС України та передумов для їх вирішення; надання курсантам під час семінарів свободи висловлення для можливості самостійно висувати пропозицій щодо поліпшення шляхів вирішення типових військово-прикладних завдань, використовуючи STEM-технології; надання консультацій та допомоги курсантам для більш детального дослідження проблеми; сприяння творчому пошуку майбутніх фрахівців: залучення курсантів до виконання конкурсних робіт, підготовки тез доповідей для виступу на наукових семінарах, практичних конореренціях тощо.

Постійне застосування зазначених засобів $€$ передумовою для профресійної самореалізації майбутніх офріцерів 3С України.

\section{БІБЛІОГРАФІЧНИЙ СПИСОК:}

1. Демент М.О., Костикова І.І., Тарадуда Д.В. Професійна діяльність майбутнього офріцера ДСНС України в сучасних умовах : монографрія. Харків : НУЦЗ України, 2018. 180 с.

2. Діденко О.В. Педагогічні умови професійного самовдосконалення майбутніх офріцерів : дис. ... канд. пед. наук : 13.00 .04 ; Національна академія Державної прикордонної служби України ім. Б. Хмельницького. Хмельницький, 2003. 201 с.

3. Діденко О.В. Теоретико-методичні засади фрормування здатності до професійної творчості в майбутніх офріцерів Державної прикордонної служби України : автореср. дис. ... д-ра наук : 13.00 .04 ; Луганський національний університет імені Тараса Шевченка. Луганськ, 2009. 42 с.

4. Іванченко Є., Свірідюк О. Педагогічні умови фрормування готовності майбутніх офріцерів збройних сил України до застосування STEM-технологій у професійній діяльності. Військова освіта. 2019. № 2(40). C. 71-81. DOI :10.33099/2617-1775/2019-02/71-81.

5. Ларіна І.О., Сиромятникова В.В. Активізація професійного самовдосконалення майбутніх вчителів у навчально-виховному процесі педагогічних університетів. Науковий часопис НПу імені М.П. Драгоманова. Серія 16: Творча особистість учителя: проблеми теорії і практики. 2011. Вип. 14. С. 245-248. URL : http://nbuv.gov.ua/ UJRN/Nchnpu_016_2011_14_60 (дата звернення: 27.12.2019).

6. Леоненко Н.В., Слободян О.П. Творчий саморозвиток особистості студента аграрного коледжу. 
Гуманітарні студії: педагогіка, психологія, фрілософрія. 2018. № 277. С. 158-162. URL : http:// journals.nubip.edu.ua/index.php/ Pedagogica/article/ view/10557/9286 (дата звернення: 20.12.2019).

7. Лісніченко Ю. Модель підготовки майбутніх офріцерів до профресійної діяльності в процесі вивчення фрахових дисциплін. Педагогічний дискурс. 2017. Вип. 22. С. 106-112.

8. Маслій О.М. Особливості підготовки майбутніх ооріцерів тилу у сорері військово-економічної логістики. Збірник наукових праць Хмельницького інституту соціальних технологій Університету «Україна». 2012. № 5. С. 135-138.

9. Ненько Ю.П. Теоретико-методологічні засади професійно орієнтованої комунікативної підготовки майбутніх офріцерів служби цивільного захисту : дис. ... д-ра пед. Наук : 13.00.04 ; Рівнен. держ. гуманітар. ун-т. Рівне, 2018. 512 с.

10. Уйсімбаєва Н.В. Характеристика категорії «самовдосконалення особистості» у психологопедагогічному контексті. Збірник наукових праць Херсонського державного університету. Педагогічні науки. 2016. Вип. 71(2). С. 62-66.

11. Уличний І. Формування готовності студентів педагогічних вищих навчальних закладів до профресійного самовдосконалення. Наукові записки Кірово- градського державного педагогічного університету імені Володимира Винниченка. Серія «Педагогічні науки». 2014. Вип. 125. С. 211-215.

12. Уличний І. Формування потенціалу просресійного самовдосконалення студенів педагогічних вищих навчальних закладів. Актуальні проблеми психології. 2014. Т. ХІІ. Психологія творчості. Вип. 19. С. $364-371$.

13. Хатунцева С.М. Саморозвиток як компонент самовдосконалення вчителя. Вісник Національної академії педагогічних наук України. Педагогіка та психологія. 2014. Вип. 45. С. 168-179.

14. Царенко О.П. Формування позитивної мотивації курсантів до навчально-ігрового проектування в процесі гуманітарної підготовки. Педагогіка фрормування творчої особистості у вищій і загальноосвітній школах. 2009. № 5(58). С. 415-420. URL : http:// pedagogy-journal.kpu.zp.ua/archive/2009/5/83.pdf (дата звернення: 13.01.2020).

15. Яблонська Т.М. Психолого-педагогічні умови активізації самовдосконалення особистості. Актуальні проблеми психології. 2015. T. 10, Вип. 27. С. 712-721. URL : http://nbuv.gov.ua/ UJRN/appsuh_2015_10_27_70 (дата звернення: 24.12.2019). 